\title{
Early Mobilization in an Oncology Intensive Care Unit
}

\section{Cristiani Caroline Carvalho, Fernanda Cristina Chavaglia Marques, Maria Luíza Alves Moreira, Monyque Evelyn Barbosa Batista, Isabella Fernandes Alves, Patricia Regina dos Reis, Daniela Santana Polati da Silveira}

Physiotherapy Department of the University of Franca, University of Franca, Franca - São Paulo, Brasil

\section{Email address:}

danielasantana@usp.com.br (D. S. P. da Silveira)

\section{To cite this article:}

Cristiani Caroline Carvalho, Fernanda Cristina Chavaglia Marques, Maria Luíza Alves Moreira, Monyque Evelyn Barbosa Batista, Isabella Fernandes Alves, Patricia Regina dos Reis, Daniela Santana Polati da Silveira. Early Mobilization in an Oncology Intensive Care Unit. Cancer Research Journal. Special Issue: Cancer, Health Care Needs and Cancer Patients' Life Quality. Vol. 8, No. 1, 2020, pp. 13-19. doi: $10.11648 /$ j.crj.20200801.13

Received: August 23, 2019; Accepted: February 13, 2020; Published: March 17, 2020

\begin{abstract}
Introduction: Quality of life and functionality of critically ill cancer patients are significantly affected after ICU admission, with changes due to immobility, hemodynamic instability, muscular atrophy, cognitive deficits, psychological difficulties, decreased cardiovascular functional capacity, neurological deleterious effects on the respiratory system. The physiotherapeutic intervention is effective in preventing and reducing the deleterious dysfunctions of immobility, as well as improving the quality of life of the patient during his / her stay in the ICU. Objective: To carry out a systematic review of literature seeking the benefits of early mobilization in intensive care patients. Methodology: Refers to a systematic literature review, approaching the PRISMA methodology, with two independent examiners who analyzed the quality of the study. We selected as inclusion criteria articles in Portuguese, English and Spanish that refer to the topic of early mobilization in intensive care oncology. Documents that do not associate with the proposed theme were excluded from the search. The articles were searched in the databases: VHL, PUBMED, COCHRANE, PEDRO and EBSCO. Results: For the elaboration of the study, 66 articles were found in the total, where only 8 articles were used because they refer to the use of early mobilization in intensive oncologic therapy. Final considerations: Early mobilization in the ICU is essential in the intervention of the multidisciplinary team on the cognitive, physical and functional aspects along with the kinesiotherapeutic progressivity adequate to the individual needs of each patient, providing significant benefits in the prevention of dysfunctions caused by the immobilism syndrome, resulting in the best quality of life for the patient.
\end{abstract}

Keywords: Early Mobilization, Intensive Care Unit, Oncology

\section{Introduction}

Cancer patient has specific pathophysiological and clinical characteristics, most often needing support in the ICU sometime during disease progression, in order to bring therapeutic support to the patient in periods of greater severity or risk. According to the world health organization, cancer is the concepto given to the set of diseases in which cells grow and spread wildly, can reach any part of the body. In 2018, presented a occurrence of more than 596 thousand cases of the disease in Brazil [1, 2].

In the ICU, critically ill patients who need to monitor and stabilize their hemodynamic condition are admitted in a sophisticated way, being possible a greater attention of the multidisciplinary team [2]. Quality of life and functionality of critically ill cancer patients are considerably affected after ICU admission with alterations caused by immobility, hemodynamic instability, muscle atrophy, cognitive impairment, psychological difficulties, decreased cardiovascular, neurological alteration, deleterious effects on the respiratory system, functional decline, delirium and others $[1,2,3]$.

Studies show that the occurrence of dysfunctions in the patient's homeostasis begins after 72 hours of admission to the ICU, and its consequences can last up to five years after hospital discharge, thus reducing the quality of life, generating a biopsychosocial imbalance and consequently generating a higher incidence of depression and anxiety [4]. 
The most favorable way for the prevention of these alterations is the physical therapy action through early mobilization in the ICU $[5,6]$.

Early mobilization consists of the initiation of physical therapy and cognitive activities in patients with mechanical ventilation within 48-72 hours of intubation onset, which begins with a multidisciplinary assessment to analyze the cognitive, physical and functional state of the patient, thus identifying and intervening according to the needs of each [1]. Activities such as stretching, positioning, use of the cycle ergometer, breathing exercises, assisted active exercises, transfer exercises, active range of motion exercises, bed mobility activities, walking, walking and others can be performed for a functional activity of the patient $[1,2,6,7$, 8]. For early mobilization to be efficient, it is important to consider the type of exercise, the intensity, frequency, dose and duration, promoting a progressive kinesiotherapy according to the patient's evolution $[2,5,7]$.

Often the patient may experience devastating fatigue, anxiety, fear, pain, boredom, insomnia (due to the turbulent environment), and most often lack motivation. This can have a negative impact on adherence to the therapist's proposed treatment, often becoming a reason for stopping early mobilization. The trust and involvement between therapist and patient is very important, as soon as you are able to establish this bond, it will begin to progress and evolve in the recovery stages, as time has come to realize and measure the functional gains that are being made [9].

The benefits of mobilization include decreased ICU stay, cardiopulmonary improvement, reduced fatigue symptoms, improved quality of life, increased muscle strength, weakness prevention, improved gastrointestinal function, pain control, decreased incidence of clot formation, pneumonia, promotion of clearance of secretions, pressure ulcers, also improving perfusion and muscle metabolismo $[1,2,3,7,9,10,11]$. The mobilization has been increasingly used as a nonpharmacological technique for pain relief, is associated with decreased sedation depth, with an excellent result, causing an increase in the number of days without mechanical ventilation. In addition, it decreases the time by 48 hours hospitalization, thus reducing hospital costs $[5,12]$. Therefore, the physical therapy intervention is highly effective in preventing and reducing deleterious dysfunctions of immobility, as well as improving the patient's quality of life during their ICU stay, thus enhancing their rehabilitation in the post-hospitalization period $[2,5]$.

\section{Methodology}

Refers to a systematic literature review performed according to the PRISMA protocol (PreferredReportItems for SystematicaReviewsand Meta-Analyses) with two independent examiners who assessed the quality of the study. In the first stage, searches were performed in five electronic databases: BVS, PUBMED, COCHRANE, PEDRO and EBSCO. The searches were performed in the English, Portuguese and Spanish languages, without starting date filter and until May 28, 2019. The search strategy given by the combination of the following keywords: "Early Mobilization, Intensive Care Unit, Oncology".

Then, there was a preliminary evaluation of titles and abstracts only, and duplicate articles that did not correspond to early mobilization in intensive cancer therapy were previously excluded. Later in the third stage, the selected studies were read in full and all those that met the inclusion criteria were included in this systematic review. Thus, any documents that do not associate with the proposed theme, and which are not of English, Portuguese or Spanish were excluded from the search (figure 1).

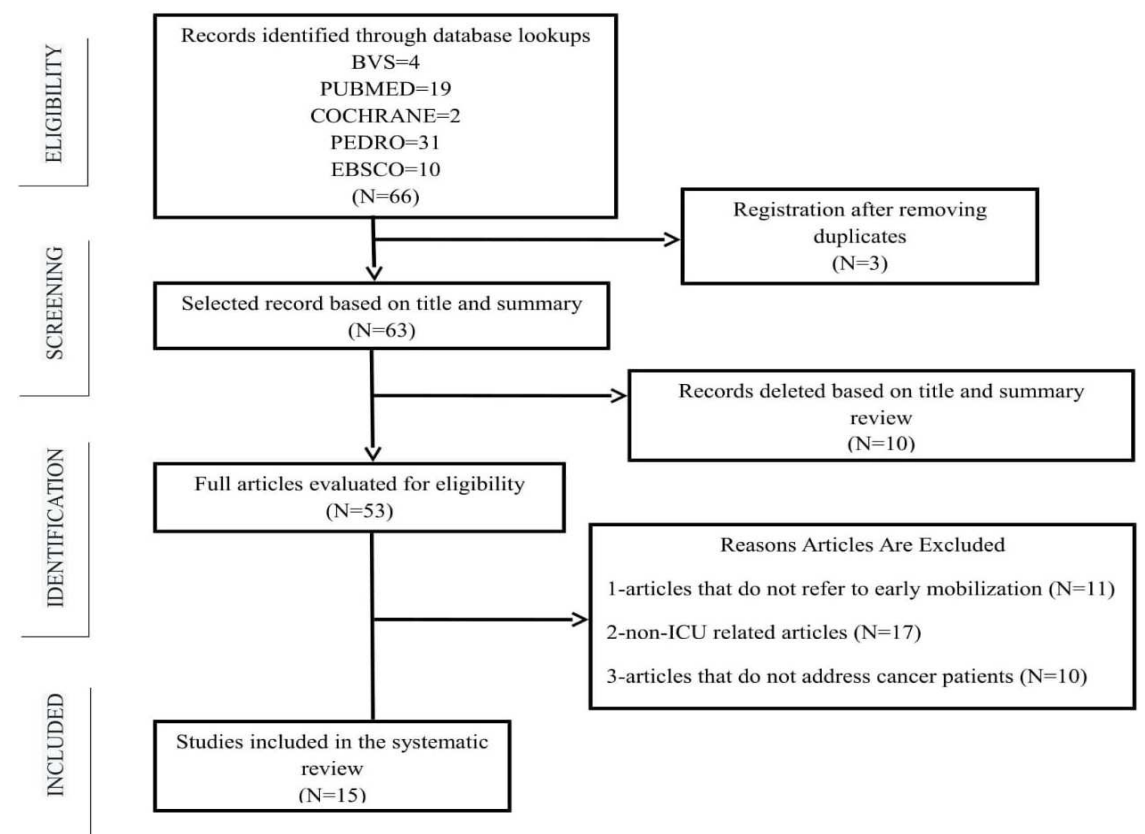

Figure 1. Schematic drawing of the applied methodology. 


\section{Results}

To prepare the study, 66 articles were found, in which only 15 articles were used (Table 1), because they refer to the use of early mobilization in intensive cancer therapy.

Table 1. 15 articles used for article construction.

\begin{tabular}{|c|c|c|c|c|c|c|}
\hline Search & Date & Author (es) & Objetive & Method & Sample & Results \\
\hline $\begin{array}{l}\text { Is there a difference } \\
\text { in early } \\
\text { mobilization } \\
\text { between } \\
\text { mechanically } \\
\text { ventilated clinical } \\
\text { and surgical } \\
\text { patients in the ICU? }\end{array}$ & 2014 & $\begin{array}{l}\text { De Matos CA, } \\
\text { De Meneses JB, } \\
\text { Bucoski SCM, } \\
\text { Mora CTR, Fréz } \\
\text { AR, Daniel CR. }\end{array}$ & $\begin{array}{l}\text { The objective was to } \\
\text { verify if there is a } \\
\text { difference in the } \\
\text { parameters and } \\
\text { outcomes of an early } \\
\text { mobilization protocol } \\
\text { among patients } \\
\text { admitted to the } \\
\text { ICU for clinical and } \\
\text { surgical reasons }\end{array}$ & $\begin{array}{l}\text { Retrospective } \\
\text { study }\end{array}$ & $\begin{array}{l}\text { We included individuals of } \\
\text { both genders, } \\
\text { over } 18 \text { years old, admitted } \\
\text { to the general ICU } \\
\text { from January to July } 2013 \\
\text { and that made } \\
\text { invasive MV use at some } \\
\text { point in the hospital, } \\
\text { regardless of the clinical } \\
\text { diagnosis. }\end{array}$ & $\begin{array}{l}\text { A general ICU with mobilization } \\
\text { protocol } \\
\text { differences were not observed in the } \\
\text { early } \\
\text { of active exercises when compared } \\
\text { patients } \\
\text { clinical and surgical. Although clinical } \\
\text { patients } \\
\text { sitting before, this did not significantly } \\
\text { impact } \\
\text { mortality or length of stay in the ICU. } \\
\text { ICU daily practices show a tendency to } \\
\text { withdraw } \\
\text { early MV patients and } \\
\text { keep them more active. }\end{array}$ \\
\hline $\begin{array}{l}\text { Qualitative, } \\
\text { Grounded Theory } \\
\text { Exploration of } \\
\text { Patients' } \\
\text { Experience of Early } \\
\text { Mobilisation, } \\
\text { Rehabilitation and } \\
\text { Recovery After } \\
\text { Critical Illness }\end{array}$ & 2019 & $\begin{array}{l}\text { Corner EJ, } \\
\text { Murray EJ, } \\
\text { Brett SJ. }\end{array}$ & $\begin{array}{l}\text { Explore the patient's } \\
\text { experience of } \\
\text { physically critical } \\
\text { illness rehabilitation } \\
\text { during and after a stay } \\
\text { in an intensive care } \\
\text { unit (ICU). }\end{array}$ & $\begin{array}{l}\text { Exploratory } \\
\text { Study of } \\
\text { Grounded } \\
\text { Theory Using } \\
\text { Semi- } \\
\text { Structured } \\
\text { Interviews }\end{array}$ & $\begin{array}{l}\text { ICU survivors with } \\
\text { acquired intensive care unit } \\
\text { (ICUAW) weakness and an } \\
\text { ICU stay> } 72 \text { hours }\end{array}$ & $\begin{array}{l}\text { Fifteen people were interviewed (with } \\
\text { four relatives present). The early } \\
\text { rehabilitation period was characterized } \\
\text { by episodic memory loss, } \\
\text { hallucinations, weakness and fatigue, } \\
\text { making early rehabilitation arduous and } \\
\text { difficult to remember. Participants } \\
\text { yearned for a paternalized process. } \\
\text { Approach to care in the early days of } \\
\text { the ICU. The central idea that emerged } \\
\text { from this study was self recalibration. } \\
\text { This is driven by a lost sense of self, } \\
\text { with loss of autonomy and competence; }\end{array}$ \\
\hline $\begin{array}{l}\text { The } \\
\text { Implementation and } \\
\text { Evaluation of an } \\
\text { Early Mobilization } \\
\text { Program for } \\
\text { Critically Ill Adult } \\
\text { Oncology Patients }\end{array}$ & 2010 & $\begin{array}{l}\text { Warren ML, } \\
\text { Pravinkumar C, } \\
\text { Frankel S, } \\
\text { Nguyen V, } \\
\text { Garcia B, } \\
\text { Thomas M, } \\
\text { Withers L, } \\
\text { Nguyen Q, } \\
\text { Brydges N. }\end{array}$ & $\begin{array}{l}\text { Increase the average } \\
\text { number of } \\
\text { mobilization activities } \\
\text { provided by a } \\
\text { multidisciplinary team } \\
\text { per patient per day by } \\
40 \% \text { after eight weeks } \\
\text { of experience. }\end{array}$ & $\begin{array}{l}\text { Estudo } \\
\text { Transversal. }\end{array}$ & $\begin{array}{l}\text { After eight weeks of EMP, } \\
\text { the average total } \\
\text { mobilization } \\
\text { Activities per patient day } \\
\text { increased by } 47 \% \text {. } \\
\text { Mobilization activities } \\
\text { carried out by } \\
\text { The bed nursing staff } \\
\text { increased by } 31 \% \text {. } \\
\text { Mobilization activities } \\
\text { carried out by } \\
\text { physiotherapists and } \\
\text { occupational therapists } \\
\text { increased } 86 \% \text { and } 78 \%, \\
\text { respectively. }\end{array}$ & $\begin{array}{l}\text { The implementation of a } \\
\text { multidisciplinary EMP in critically ill } \\
\text { patients has led to a } \\
\text { increase in the number of mobilization } \\
\text { activities per patient day. Using an } \\
\text { Alan Fields Award Winner: Practitioner } \\
\text { with 2+ years of experience } \\
\text { patient-centered approach, } \\
\text { interdisciplinary team and quality } \\
\text { improvement } \\
\text { The process ensured the success and } \\
\text { sustainability of the program. }\end{array}$ \\
\hline $\begin{array}{l}\text { A Descriptive } \\
\text { Report of Early } \\
\text { Mobilization for } \\
\text { Critically Ill }\end{array}$ & 2018 & $\begin{array}{l}\text { Weeks A, } \\
\text { Campbell C, } \\
\text { Rajendram P, } \\
\text { Shi w, Voigt L. }\end{array}$ & $\begin{array}{l}\text { Investigate feasibility } \\
\text { of early mobilization } \\
\text { and describe } \\
\text { rehabilitation }\end{array}$ & $\begin{array}{l}\text { Retrospective } \\
\text { Review Study. }\end{array}$ & $\begin{array}{l}\text { The study was conducted in } \\
\text { a } 20 \text {-bed medical / surgical } \\
\text { ICU at a tertiary treatment } \\
\text { center. }\end{array}$ & $\begin{array}{l}\text { A cohort of } 42 \text { cancer patients on } \\
\text { mechanical ventilation at the mixed / } \\
\text { surgical hospital } \\
\text { intensive care unit of a comprehensive }\end{array}$ \\
\hline
\end{tabular}




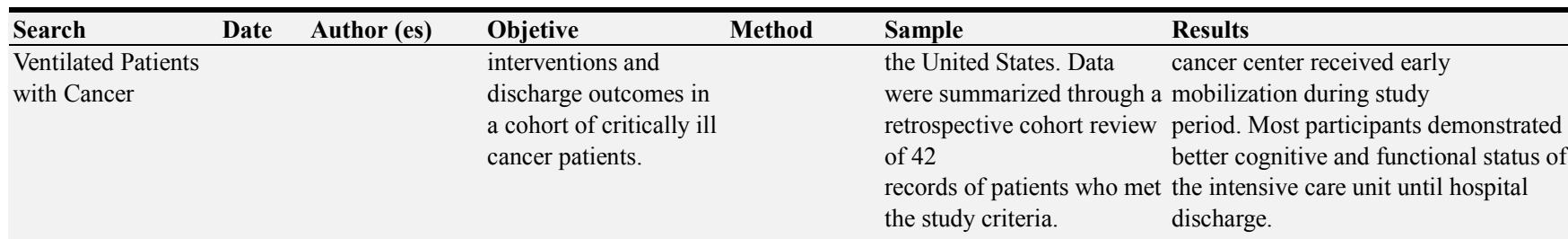

$\begin{array}{lll} & \text { De Almeida } \\ & \text { EPM, De } \\ & \text { Almeida JP, } \\ \text { Early Mobilization } & \text { Landoni G, } \\ \text { Programme } & \text { Galas FRBG, Evaluate the } \\ \text { Improves } & \text { Fukushima JT, effectiveness, } \\ \text { Functional } & \text { Fominskiy E, feasibility and } & \\ \text { Capacity After } 2017 & \text { De Brito CMM, safety of a supervised Study } \\ \text { major Abdominal } & \text { Cavichio LBL, postoperative exercise } \\ \text { Cancer Surgery: A } & \text { De Almeida program. } \\ \text { Randomized } & \text { LAA, Osawa } \\ \text { Controlled Trial } & \text { EA, Diz MPE, } \\ & \text { Cecatto RB, } \\ & \text { Battistella LR, } \\ & \text { Hajjar LA. }\end{array}$

Physiotherapy Led

Early

Rehabilitation Of

The Patient With

Critical Illness

Enhanced Recovery

Decreases

Pulmonary and

Cardiac

Complications

Following

Thoracotomy for

Lung Cancer

Thomas AJ.

Examine reports describing the effects of physical rehabilitation which is started immediately on intensive care admission compared to rehabilitation that is delayed.

Haren RMV,

Mehran RJ,

Correa AM,

Antonoff MB,

Baker CM,

Woodard TC,

Evaluate results after

ERAS implementation

in patients undergoing Retrospective

Hofstetter WL,

Mena GE, Roth

resection for

pulmonary

JA, Sepesi B, malignancy.

Review.

Study observation period but only

Observational $20(9 \%)$ were enrolled in program.

Swisher SG, pulmonary resection for
All patients in the

Research of the University of São Paulo School of Medicine

Paulo, Brazil). Written informed consent was obtained from all patients or their legal substitute group were able to follow at least partially the exercise program, although the performance between them heterogeneous. There were no differences between groups regarding clinical outcomes or exercise-related complications.

Vaporciyan AA,

Walsh GL, Rice

DC.

Physical Therapist-

Established

Intensive Care Unit

Early Mobilization

Program: Quality

Improvement

Project for Critical

Care at the

University of

California San

Francisco Medical

Center

Thromboprophylax is and Major

Oncologic Surgery 2013

Performed With

Epidural Analgesia

Engel HJ, Improvements in

Tatebe s, Alonzo demonstrated the value

PB, Mustille and feasibility of an Study of

RL, Rivera MJ. early mobilization Retrospective

program conducted by

physiotherapists

Shouhed D,

To evaluate clinical Amersi F, Sibert outcomes in patients Amersi F, Sibert with Hemaya E, Silbermam AW. cancer who underwent prospective major abdominal surgeries that received with analysis of a

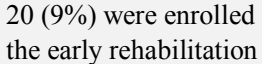

Two hundred and twentyfive patients were admitted during the 5-month

Overall, early onset of rehabilitation shows increased incidence of physical therapy

consultation, decreased time to reach activity goals, improved functional outcomes in intensive care unit and hospital discharge and reduce direct patient costs.
They compared the results of patients undergoing primary lung cancer.
A total of 2,886 pulmonary resections were analyzed.

For all patients, the length of hospitalization, Pulmonary complications were, and Cardiac complications

decreased. There were no differences in hospital readmission.

From 2009 to 2010, the number of patients undergoing physiotherapy treatment in the ICU increased from 179 to 294 . The average times

An interprofessional early (interquartile intervals) of ICU ICU mobilization group admission to the physiotherapy established and promoted assessment were 3 days (9 days) in guidelines for mobilizing ICU patients. 2009 and 1 day (2 days).) in 2010. The length of stay in the ICU decreased by an average of 2 days, and the percentage of outpatients discharged from home increased from $55 \%$ to $77 \%$.

Between January 1, 2009 The average operative time was 338 minutes.

The average stay in the intensive care

and July 31,2011 ,

19 patients, with a mean age of 64.5 years (range 34 to years), underwent major
(PD) was 2.8 (1.4) days. (range: 1-7 days). Postoperative 


\begin{tabular}{|c|c|c|c|c|c|c|}
\hline Search & Date & Author (es) & Objetive & Method & Sample & Results \\
\hline $\begin{array}{l}\text { Delayed } \\
\text { Mobilization After } \\
\text { Microsurgical } \\
\text { Reconstruction: An } \\
\text { Independent Risk } \\
\text { Factor for } \\
\text { Pneumonia }\end{array}$ & 2013 & $\begin{array}{l}\text { Yeung JK, } \\
\text { Harrop R, } \\
\text { McCreary O, } \\
\text { Leung LT, } \\
\text { Hirani N, } \\
\text { McKenzia D, } \\
\text { De Haas V, } \\
\text { Matthews W, } \\
\text { Nakoneshny S, } \\
\text { Dort JC, Schrag } \\
\text { C. }\end{array}$ & $\begin{array}{l}\text { preoperative epidural } \\
\text { catheters (ECs) } \\
\text { and without } \\
\text { postoperative } \\
\text { thromboprophylaxis } \\
\text { To determine the } \\
\text { incidence of pneumonia } \\
\text { among patients } \\
\text { undergoing } \\
\text { mouth cancer resection } \\
\text { and immediate free flap } \\
\text { reconstruction and to } \\
\text { compare the incidence } \\
\text { of this complication } \\
\text { early mobilized patients } \\
\text { ( }<4 \text { days } \\
\text { postoperatively) versus } \\
\text { later. }\end{array}$ & $\begin{array}{l}\text { Retrospective } \\
\text { cohort study. }\end{array}$ & $\begin{array}{l}\text { Sixty-two consecutive } \\
\text { patients treated between } \\
2005 \text { and } 2009 \text { with } \\
\text { resection of oral carcinoma } \\
\text { and free flap. Information } \\
\text { regarding comorbidities, } \\
\text { postoperative care and } \\
\text { complications was } \\
\text { collected. }\end{array}$ & $\begin{array}{l}\text { The incidence of pneumonia was } \\
30.6 \% \text {. Longer stay in the intensive } \\
\text { care unit, tracheostomy decannulation } \\
\text { after } 10 \text { days and longer operative } \\
\text { times. Were significantly associated } \\
\text { with pneumonia. Delayed mobilization } \\
\text { (after day } 4 \text { postoperatively) was an } \\
\text { independent risk factor for pneumonia. }\end{array}$ \\
\hline $\begin{array}{l}\text { Current practices of } \\
\text { mobilization, } \\
\text { analgesia, relaxants } \\
\text { and sedation in } \\
\text { Indian ICUs: a } \\
\text { survey conducted } \\
\text { by the Indian } \\
\text { Society of Intensive } \\
\text { Care Medicine }\end{array}$ & 2014 & $\begin{array}{l}\text { Chawla R, } \\
\text { Myatra SN, } \\
\text { Dash SK. }\end{array}$ & $\begin{array}{l}\text { Compare the incidence } \\
\text { of complication } \\
\text { early mobilized } \\
\text { patients ( }<4 \text { days } \\
\text { postoperatively) versus } \\
\text { later. }\end{array}$ & $\begin{array}{l}\text { National web- } \\
\text { based search. }\end{array}$ & $\begin{array}{l}\text { A questionnaire included } \\
\text { questions on demographic } \\
\text { data, assessment scales for } \\
\text { delirium, sedation and pain, } \\
\text { as well as pharmacological } \\
\text { agents and methods of } \\
\text { practice. }\end{array}$ & $\begin{array}{l}\text { Most respondents were aware of the } \\
\text { benefits of early mobilization, but lack } \\
\text { of support staff and security concerns } \\
\text { were major obstacles to their } \\
\text { implementation. }\end{array}$ \\
\hline $\begin{array}{l}\text { Mobilization in the } \\
\text { Intensive Care } \\
\text { Unit: systematic } \\
\text { review }\end{array}$ & 2014 & $\begin{array}{l}\text { Silva VS, Pinto } \\
\text { JG, Martinez } \\
\text { BP, Camelier } \\
\text { FWR. }\end{array}$ & $\begin{array}{l}\text { Systematize the } \\
\text { knowledge about PM } \\
\text { in the intensive care } \\
\text { environment and its } \\
\text { repercussion, } \\
\text { especially on the } \\
\text { functional and } \\
\text { permanence aspects of } \\
\text { mechanical ventilation } \\
\text { (MV) and the ICU. }\end{array}$ & $\begin{array}{l}\text { Systematic } \\
\text { review }\end{array}$ & $\begin{array}{l}\text { Only clinical trials with } \\
\text { Control Group }(\mathrm{CG}) \text { and } \\
\text { full access availability were } \\
\text { included, which evaluated } \\
\text { the effect of PM on the } \\
\text { ICU in adult humans over } \\
18 \text { years. }\end{array}$ & $\begin{array}{l}\text { Early mobilization in the Intensive } \\
\text { Care Unit had a significantly positive } \\
\text { impact on patients' functional } \\
\text { outcomes. }\end{array}$ \\
\hline $\begin{array}{l}\text { Effects of motor } \\
\text { physical therapy in } \\
\text { critically ill } \\
\text { patients: literature } \\
\text { review }\end{array}$ & 2010 & $\begin{array}{l}\text { Da Silva APP, } \\
\text { Maynard K, Da } \\
\text { Cruz MR. }\end{array}$ & $\begin{array}{l}\text { Review the literature } \\
\text { related to the use of } \\
\text { kinesiotherapy in } \\
\text { intensive care unit } \\
\text { patients }\end{array}$ & $\begin{array}{l}\text { Literature } \\
\text { review }\end{array}$ & $\begin{array}{l}\text { Through the MedLine, } \\
\text { LILACS, CINAHL, } \\
\text { Cochrane, High Wire Press } \\
\text { and SciELO electronic } \\
\text { databases from January } \\
1998 \text { to July } 2009 \text { and book } \\
\text { chapters using keywords } \\
\text { including: critical illness, } \\
\text { kinesiotherapy, } \\
\text { physiotherapy, exercises, } \\
\text { training, force, active } \\
\text { mobilization, mobilization, } \\
\text { ICU, rehabilitation, } \\
\text { mobility, uscle } \\
\text { strength "and“ weakness }\end{array}$ & $\begin{array}{l}\text { Despite the scarcity of studies and the } \\
\text { methodological diversity of studies } \\
\text { showing the use of kinesiotherapy as a } \\
\text { therapeutic resource, its use, even early } \\
\text { seems to be an alternative to the } \\
\text { prevention and reversal of muscle } \\
\text { weakness acquired in the intensive care } \\
\text { unit. }\end{array}$ \\
\hline $\begin{array}{l}\text { Early intervention } \\
\text { (mobilization or } \\
\text { active exercise) for } \\
\text { critically ill adults } \\
\text { in the intensive care } \\
\text { unit (Review) }\end{array}$ & 2018 & $\begin{array}{l}\text { Doiron KA, } \\
\text { Hoffmann TC, } \\
\text { Beller EM }\end{array}$ & $\begin{array}{l}\text { To evaluate the effects } \\
\text { of early intervention } \\
\text { (mobilization or active } \\
\text { exercise) initiated in } \\
\text { the ICU, provided to } \\
\text { critical adults during or } \\
\text { after the period of } \\
\text { mechanical ventilation, } \\
\text { compared with late } \\
\text { exercise or usual care, } \\
\text { on improving physical } \\
\text { function or } \\
\text { performance, strength } \\
\text { muscle and health- } \\
\text { related quality of life. }\end{array}$ & $\begin{array}{l}\text { Study } \\
\text { Systematic } \\
\text { Reviews }\end{array}$ & $\begin{array}{l}\text { Data collection and } \\
\text { analysis } \\
\text { Two researchers } \\
\text { independently selected } \\
\text { titles and abstracts and } \\
\text { evaluated full-text articles } \\
\text { based on the inclusion } \\
\text { criteria of this review. } \\
\text { We resolve any } \\
\text { disagreement by discussing } \\
\text { with a third reviewer as } \\
\text { needed. }\end{array}$ & $\begin{array}{l}\text { There were mixed results on the effect } \\
\text { of early movement or exercise on } \\
\text { function. } \\
\text { One study found that in some measures } \\
\text { of physical function, participants who } \\
\text { received the intervention could get out } \\
\text { of bed earlier } \\
\text { and walk greater distances. } \\
\text { Early movement or exercise seems safe } \\
\text { because the number of adverse events } \\
\text { was very low. There was no difference } \\
\text { between the groups. } \\
\text { time spent in hospital, muscle strength } \\
\text { or mortality rates }\end{array}$ \\
\hline
\end{tabular}




\section{Discussion}

According to Murakami FM et al, technological advances and care for critically ill patients contribute to a high prevalence of patients who responded to early mobilization, and the clinical or surgical diagnosis does not interfere with the response of these patients, significantly contributing to decreased mortality, increased patient survival, which is of interest in always improving the adverse effects of immobility [2]. According to De Matos CA et al, there is a positive response related to patient survival and lower mortality rate with early mobilization interventions in intensive care units [1].

From Almeida EPM et al and Shouhed D et al, evidence that a postoperative early mobilization program seems to be safe and viable, working with exercises that improve fatigue, improve quality of life, increase muscle strength and decrease the incidence of clot formation.

Therefore in his study no clear clinical results were found $[6,10]$. As stated by Thomas AJ et al, that physiotherapy conducts early rehabilitation as a component of ICU management, shows concern about the effectiveness of interventions provided beyond routine care, with this as a significantly positive response [7].

Silva VS et al, show that the frequency and severity of neuromuscular weakness and its clinical manifestations can be minimized by the application of early mobilization (MP) that acts in the prevention and treatment of these complications. Early physical therapy, even during the time of intubation and ventilatory support, can be safely practiced, improving patient functional outcomes [13].

Corner EJ et al, concluded through a survey of the patient's experience of early mobilization in the ICU that patients agreed with the relevance of early mobilization but found it difficult, tiring and uncomfortable [3].

Warren ML et al and Haren RMV et al present that mobilization activities performed by physiotherapists have increased, bringing the benefit of reduced time in an intensive care unit $[4,8]$. For Weeks $\mathrm{A}$ et al, evidence that the functionality and quality of life of critically ill patients worsen when admitted to the ICU, but the study indicates that there must be cognitive and physical interventions as they are potentially viable in cancer patients to treat the limitation of functional performance [5].

Chawla $\mathrm{R}$ et al stated that most physicians are aware of the gains that mobilization brings to the patient, but their implementation is still limited due to lack of support and concern for their safety, and that mobilization depends on sedation-analgesia and ICU muscle rest [12]. Already Yeung JK et al, reported that several microsurgeons resist adopting mobilization protocols due to possible complications such as graft loss and skin discontinuation, so prefer to avoid [11].

For Silva AP et al, the exercises have well-stipulated physical and psychological gains, also reduce oxidative stress and inflammation, by providing the growth of anti- inflammatory cytokines production [14].

According to Doiron KA et al, patients admitted to the intensive care unit require greater stabilization and monitoring attention, however, to be effective early mobilization has to take into account the type of exercise, frequency that is applied and dose and duration in these critically ill patients [15]. However, Engel HJ et al, says how favorable is the role of the physiotherapist in this early intervention in patient health, preventing changes and improving quality of life while in the ICU, thus promoting the rehabilitation of cancer patients [9].

\section{Final Considerations}

According to the analysis of the data obtained through this systematic literature review, it is noted that early ICU mobilization is highly effective in addressing the multidisciplinary team on cognitive, physical and functional aspects along with kinesio therapeutic progressivity appropriate to the individual needs of patients, providing significant benefits in preventing dysfunctions caused by the immobility syndrome, resulting in a better quality of life for the patient.

\section{References}

[1] De Matos CA, De Meneses JB, Bucoski SCM, Mora CTR, Fréz AR, Daniel CR. Is there a difference in early mobilization between mechanically ventilated clinical and surgical patients in the ICU? Matos et al. Mechanical ventilation and mobilization. 2014; 23: 124-126.

[2] Murakami FM, Yamguti WP, Onove MA, Mendes JM, Pedrosa RS, Maida ALV, De Salles ICD, De Brito CMM, Rodrigues MK. Functional evolution of critically ill patients undergoing an early rehabilitation protocol. Brazilian Journal of Intensive Care. 2015; 27 (2): 162-163.

[3] Corner EJ, Murray EJ, Brett SJ. Qualitative, grounded theory exploration of patients' experience of early mobilisation, rehabilitation and recovery after critical illness. BMJ Open. 2019; 9 (2): 1-2

[4] Warren ML, Pravinkumar C, Frankel S, Nguyen V, Garcia B, Thomas M, Withers L, Nguyen Q, Brydges N. The Implementation and Evaluation of an Early Mobilization Program for CriticallyIll Adult Oncology Patients. University of Texas MD Anderson Cancer Center. 2010; 39 (12) 1-2.

[5] Weeks A, Campbell C, Rajendram P, Shi w, Voigt L. A Descriptive Report of Early Mobilizationfor Critically Ill Ventilated Patients with Cancer. HHS Public Access. 2018; 35 (3): 2-4.

[6] De Almeida EPM, De Almeida JP, Landoni G, Galas FRBG, Fukushima JT, Fominskiy E, De Brito CMM, Cavichio LBL, De Almeida LAA, Osawa EA, Diz MPE, Cecatto RB, Battistella LR, Hajjar LA. Early mobilization programme improves functional capacity after major abdominal cancer surgery: a randomized controlled trial. The Cochrane Collaboration. 2017; 19 (5): 1-3. 
[7] Thomas AJ. Physiotherapy led early rehabilitation of the patient with critical illness. Physical Therapy Reviews. 2011; 16: $1-2$.

[8] Van Haren RM, Mehran RJ, Mena GE, Correa AM, Antonoff MB, Baker CM, Woodard TC, Hofstetter WL, Roth JA, Sepesi B, Swisher SG, Vaporciyan AA, Walsh GL, arroz DC. Enhanced recovery decreases as pulmonary and cardiac complications following a thoracotomy for lung cancer. Ann Thorac Surg. 2018; 106 (1): 272-279.

[9] Engel HJ, Tatebe s, Alonzo PB, Mustille RL, Rivera MJ. Physical Therapist-Established Intensive Care Unit Early Mobilization Program: Quality Improvement Project for Critical Care at the University of California San Francisco Medical Center. 2014; 93 (7): 974-975.

[10] Shouhed D, Amersi F, Sibert T, Sibert K, Hemaya E, Silberman A. Thromboprophylaxis and Major Oncologic Surgery Performed With Epidural Analgesia. JAMA Surg. 2013; 148 (1): 81-4.

[11] Yeung JK, Harrop R, McCreary O, Leung LT, BPharm LL, Hirani N, McKenzie D, Haas V, Matthews w, Nakoneshny S,
Dort J, Schrag C. Delayed Mobilization After microsurgical Reconstruction: Na Independent. The Laryngoscope. 2013; 123 (12): 2996-3000.

[12] Chawla R, Myatra Sn, Ramakrishnan N, Todi A, Kansal S, Dash SK. Current practices of mobilization, analgesia, relaxation and sedation in Indian ICUs: a 575-584.

[13] Silva VS, Pinto JG, Martinez BP, Camelier FWR. Mobilization in the Intensive Care Unit: systematic review Movilización en la Unidad de Cuidados Intensivos: revisión sistemática. Fisioter Pesq. 2014; 21 (4): 398-404.

[14] Silva APP, Maynard K, Cruz MR. Effects of motor physical therapy in critically ill patients: literature review. Rev Bras Ter Intensiva. 2010; 22 (1): 85-91.

[15] Doiron KA, Hoffmann TC, Beller EM. Early intervention (mobilization or active exercise) for critically ill adults in the intensive care unit. Cochrane Database of Systematic Reviews. 2018; 10: 1-2. 